\title{
Wolność słowa w sieci
}

Agnieszka Latarska | Wydział Nauk Społecznych, Uniwersytet Gdański

\section{Streszczenie}

Słowa kluczowe:

wolność,

wolność słowa, prawo, ksenofobia, ograniczenie

Keywords:

freedom,

freedom

of expression, law, xenophobia,

restriction
Celem niniejszego artykułu jest przedstawienie, czym tak naprawdę jest wolność słowa w sieci. Wolność, do której każdy z nas ma prawo, ale którą ogranicza się coraz częściej ze względu na nierzadkie przejawy mowy nienawiści, ksenofobii czy rasizmu. Wolność słowa to prawo do publicznego wyrażania własnych myśli i poglądów, współcześnie uznawane jako standard wśród norm cywilizacyjnych. Dzisiaj jednak spotykamy się z jej ograniczeniami.

W niniejszym artykule analizuję, jakie są przejawy mowy nienawiści w Internecie, a także jej przyczyny, które blokują swobodę wyrażania myśli.

\section{Freedom of speech on the Internet}

\section{Summary}

The aim of this article is to present what freedom of speech on the web really is. Freedom, to which each of us has a right, but which is increasingly restricted by the growing manifestations of hate speech, xenophobia and racism. Freedom of speech is the right to publicly express one's thoughts and beliefs, nowadays considered as a standard among the norms of civilization. Today, however, we are increasingly confronted with limitations.

In this article I analyse the manifestations of hatred on the Internet, its causes, which are a direct blockade of freedom of speech in the online world. 


\section{Wstęp}

Celem niniejszego artykułu jest przedstawienie, czym tak naprawdę jest we współczesnym świecie wolność słowa w sieci. To swojego rodzaju swoboda, do której powinniśmy mieć prawo, ale ze względu na przejawy mowy nienawiści, ksenofobii i rasizmu jest ona ograniczana.

„Więc mnie dręczy myśl niezdrowa: Czy jest w Polsce wolność słowa?” pisał Jan Brzechwa w wierszu Wolność słowa. Dzisiaj zadajemy sobie dokładnie to samo pytanie. Jako że żyjemy w państwie demokratycznym, każdy z nas ma prawo do wyrażania swoich myśli i poglądów. Gwarantuje to choćby Europejska Konwencja Praw Człowieka. Mowa w niej o braku cenzury i ograniczeń w wyrażaniu własnej opinii, czyli najważniejszych wolnościach obywatelskich. To fundament państwa demokratycznego, który pozwala wyrażać swoje stanowisko np. poprzez prasę czy telewizję. Prawo to ma jednak ograniczenia związane z poszanowaniem praw innego człowieka, bezpieczeństwem narodowym oraz ochroną moralności. Zakazana jest obraza m.in. uczuć religijnych, a karze podlegają wszelkie wypowiedzi sugerujące naruszenie czyjegoś bezpieczeństwa lub zniesławienie drugiej osoby. Wolność słowa nie może ingerować w obszar wolności innego człowieka.

Wolność słowa w sieci w praktyce wygląda trochę inaczej. Według mnie jesteśmy na dobrej drodze do rzeczywistości, w której m.in. rządzący będą nam dyktować, co i na jakim portalu mamy czytać i w jakich dyskusjach zabierać głos. Do rzeczywistości internetowej cenzury, gdzie większość niewygodnych postów i komentarzy będzie usuwanych ze strachu przed ewentualnymi karami - przecież nie tak dawno, bo na początku stycznia 2018 r., w Niemczech zaproponowano nowe zasady walki z mową nienawiści w Internecie. Rozwiązaniem ma być możliwość nałożenia kary w wysokości od 5 do nawet 50 mln euro na firmy zajmujące się mediami społecznościowymi, jeśli nie usuną zgłoszonych treści w ciągu 24 godzin. Pod lupą mają się znaleźć największe i najbardziej znane portale społecznościowe, jak Facebook, Twitter, YouTube czy Instagram. Jestem przekonana, że ustawa umożliwi także usuwanie wpisów i komentarzy działających na niekorzyść rządzących lub tych, którzy mają większe przywileje od przeciętnego obywatela.

Polski rząd miał zająć się walką z niewłaściwymi wpisami w Internecie, działającymi na niekorzyść rządzących, tzw. fake news. Ten sam rodzaj walki z niewłaściwymi wpisami miał funkcjonować w Indiach. Decydenci planowali nakładać karę na dziennikarzy, którzy publikują wspomniane fake news. Miała to być swego rodzaju kontrola mediów przed wyborami, które odbędą się w Indiach w przyszłym roku. Dziennikarzom planowano anulować akredytacje, które są wymagane w ministerstwach i innych instytucjach rządowych, a także na konferencjach prasowych. Na szczęście władze Indii wycofały się z pomysłu, ale powodów zmiany tej decyzji już nie podano. 
Czym jest wspomniany fake news? To nic innego jak przekazywanie informacji, której celem jest dezinformacja lub oszustwo. Sam termin oznacza dosłownie „fałszywe wiadomości", które mają wprowadzić w błąd widza, czytelnika lub słuchacza. Co ciekawe, informacje te nie mają żadnego odzwierciedlenia w świecie rzeczywistym, a i tak są powszechne w mediach i portalach społecznościowych, siejąc zamęt wśród odbiorców i zagłuszając prawdziwy i rzetelny materiał dziennikarski.

Wolność słowa w sieci powinna opierać się na wzajemnym szacunku i tworzeniu przyjaznego środowiska. Niestety, większości z nas wydaje się, że Internet to przestrzeń, w której możemy publikować słowa bez konsekwencji. Anonimowość jeszcze bardziej zachęca użytkowników do coraz bardziej swobodnego, a nawet skrajnego tonu wypowiedzi. Bardzo często internauci wchodzą w dyskusje, w których dochodzi do ostrej wymiany zdań i wzajemnych oskarżeń. W tym momencie na każdej stronie internetowej lub forum do akcji wkracza moderator, czyli osoba, która zajmuje się usuwaniem niestosownych komentarzy. Każdy z nas może także zgłosić komentarz do moderatora, jeśli uznamy, że jest on obraźliwy. Coraz częstszą praktyką jest także likwidacja stron, jak np. tych na portalu Facebook. To tak zwana walka z mową nienawiści i organizacjami nacjonalistycznymi. To właśnie na ich profilach społecznościowych dochodzi do eskalacji zachowań rasistowskich i ksenofobicznych. Takie działania budzą jednak skrajne emocje - w Polsce likwidacja tych stron wywołała krytykę i demonstracje, których hasłem przewodnim była obrona wolności słowa, zaś w Niemczech domagano się stanowczych działań przeciwko niestosownym treściom w mediach społecznościowych (Ruchniewicz 2018).

\section{Blokada wyjściem z sytuacji?}

Jak pisze Bartosz Chyż na łamach "Gazety Wyborczej” w artykule Blokowanie stron na Facebooku - ofiarami padli nie tylko 'narodowcy', w ciągu ostatnich sześciu lat zablokowano prawie 1,3 tys. polskich profili na Facebooku; co więcej, nie należały one jedynie do narodowców. Jak wymienił autor, ze strony zniknęły profile organizacji nacjonalistycznych: Marszu Niepodległości, Młodzieży Wszechpolskiej, Obozu Narodowo-Radykalnego i Ruchu Narodowego. Blokowano także prywatne profile działaczy ruchów narodowych, głównie z powodu łamania regulaminu serwisu.

Narodowi działacze oskarżyli administratorów Facebooka o cenzurę i ograniczanie wolności słowa. W odwecie blokowali konto Facebooka na Twitterze. Wstawiła się za nimi minister cyfryzacji Anna Streżyńska, która prosiła o rozmowę z przedstawicielami serwisu. Richard Allan, wicedyrektor koncernu na Europę, Bliski Wschód i Afrykę, tłumaczył, że strona Marszu Niepodległości „została usunięta po publikacji szeregu postów naruszających nasze standardy w zakresie mowy nienawiści". Przede wszystkim chodziło o znak falangi, czyli symbol międzywojennego, faszyzującego ONR-Falanga, a dziś m.in. ONR i Narodowego Odrodzenia Polski (Chyż 2018). 
Musimy mieć jednak świadomość tego, że nie sposób uniknąć wszystkich niestosownych komentarzy. Nawet bieżący monitoring nie uchroni stron internetowych od wulgarnych treści.,"Gazeta Wyborcza” ułatwiła zadanie swoim moderatorom - zablokowała możliwość zamieszczania komentarzy pod artykułami związanymi z uchodźcami, migrantami i muzułmanami, wiedząc, że nawet w ciągu kilkunastu minut pojawią się wulgarne i rasistowskie wypowiedzi. Internauci próbowali przechytrzyć dziennikarzy, wyrażając swoje myśli pod innymi, przypadkowymi artykułami, zaznaczając czego owa „mądrość" dotyczy. Warto dodać, że w Internecie mimo wszystko nikt nie jest anonimowy. Każdy administrator danej strony, portalu czy forum jest w stanie zlokalizować konkretnego użytkownika.

Co z osobami publicznymi? Nie zapominajmy, że ze względu na swoją działalność w przestrzeni publicznej na krytykę są narażone wszystkie osoby publiczne. W tym wypadku prawo nie działa tak rygorystycznie. Wolność słowa kończy się wówczas, kiedy wypowiedź, treść lub komentarz w mediach społecznościowych jest niewygodny dla osoby opisywanej, która np. zajmuje wysokie stanowisko czy jest rozpoznawalna. Niekoniecznie mowa o obraźliwych wpisach. Oczywiście, jak można przeczytać w materiałach z konferencji Mowa nienawiści w internecie: jak z niq walczyć?, istnieje wielka różnica między celowym zniesławianiem, obrażaniem, szczuciem, a krytycznym dyskursem publicznym:

Wolność słowa i wolność wyrażania poglądów nie usprawiedliwia naruszania praw i wolności innych - to elementarz praw człowieka. Dlatego nie przekonują mnie ci, którzy uważają, że w internecie i właśnie akurat w nim, tylko dlatego, że jest internetem, można umieścić wszystko o wszystkim. W internecie wolno tyle i tylko tyle, ile wolno w innych mediach. Ani mniej, ani więcej. Medium jest obojętne, a granicą wolności słowa - niezależnie od tego, gdzie jest głoszone - są prawa i wolności innych ludzi, ich godność i prywatność. Dlatego sympatyzując z ideą apelu Tygodnika Powszechnego, akcent kładłam nie tyle na potrzebę 'nowego prawa' (zresztą, jak się dobrze przyjrzeć polskiemu prawu, to te niby nowe propozycje wcale nie są takie nowe), co na czynienie dobrego użytku przede wszystkim z tego, co już jest dostępne jako ochrona przed 'złym słowem'. 'Złe słowo' to słowo szczujące, raniące, poniżające, szydzące, nawołujące do czynów gwałtownych. Ale też - przyznam - nie zaliczam do tej kategorii prześmiewczej satyry czy karykatury (nawet ostrej - dlatego nie przekonuje mnie konieczność interwencji we wczesnych godzinach rannych w domu internauty umieszczającego satyryczne rysuneczki czy filmiki). Nie przekonuje mnie karanie internauty za zniewagę prezydenta, podobnie jak zresztą karanie piosenkarki za żart z Biblii (Bychowska-Siniarska, Głowacka 2018).

\section{Od Facebooka do nienawiści}

Z tymi, którzy uważają, że w Internecie można wszystko, bez żadnych konsekwencji, walczy Ośrodek Monitorowania Zachowań Rasistowskich i Ksenofobicznych. Ośrodek "skutecznie staje na drodze brunatnej fali zalewającej Polskę". Jak piszą na swoim profilu na Facebooku, ich „celem jest doprowadzenie do jak największej ilości procesów, 
w których do odpowiedzialności mieliby zostać pociągnięci liderzy i ideolodzy neofaszystowskich bojówek". Codziennie opracowują zgłoszenia o popełnieniu przestępstw z nienawiści, pomagają ofiarom prześladowań i raportują o aktualnej sytuacji w Polsce. Na swojej stronie internetowej informują:

Nawoływanie do nienawiści jest przestępstwem takim samym jak kradzież, pobicie, gwałt. I tak samo, jak inne przestępstwa powoduje cierpienie konkretnych osób. Wyobraź sobie, że każdy nienawistny komentarz to jedno uderzenie w policzek. Każdy obraźliwy mural to jedno splunięcie w twarz. Ofiarami są konkretni ludzie (...).

\section{Dalej przytaczają poszczególne artykuły Kodeksu karnego:}

$\S 1$. Kto publicznie propaguje faszystowski lub inny totalitarny ustrój państwa lub nawołuje do nienawiści na tle różnic narodowościowych, etnicznych, rasowych, wyznaniowych albo ze względu na bezwyznaniowość, podlega grzywnie, karze ograniczenia wolności albo pozbawienia wolności do lat 2 .

$\S 2$. Tej samej karze podlega, kto w celu rozpowszechniania produkuje, utrwala lub sprowadza, nabywa, przechowuje, posiada, prezentuje, przewozi lub przesyła druk, nagranie lub inny przedmiot, zawierające treść określoną w $§ 1$ albo będące nośnikiem symboliki faszystowskiej, komunistycznej lub innej totalitarnej.

§3. Nie popełnia przestępstwa sprawca czynu zabronionego określonego w § 2, jeżeli dopuścił się tego czynu w ramach działalności artystycznej, edukacyjnej, kolekcjonerskiej lub naukowej.

$\S 4$. W razie skazania za przestępstwo określone w $\S 2$ sąd orzeka przepadek przedmiotów, o których mowa w $\S 2$, chociażby nie stanowiły własności sprawcy.

Art. 257 Kodeksu karnego: Kto publicznie znieważa grupę ludności albo poszczególną osobę z powodu jej przynależności narodowej, etnicznej, rasowej, wyznaniowej albo z powodu jej bezwyznaniowości lub z takich powodów narusza nietykalność cielesną innej osoby, podlega karze pozbawienia wolności do lat 3.

Ośrodek Monitorowania Zachowań Rasistowskich i Ksenofobicznych zgłasza prokuraturze wszelkie podejrzenia popełnienia przestępstwa z ww. artykułów Kodeksu karnego. Jak czytamy:

nawoływaniem do nienawiści, bądź propagowaniem ustroju totalitarnego mogą być zarówno wpisy internetowe, jak i wypowiedzi publiczne, teksty piosenek, wykonywanie gestów i używanie symboli kojarzonych z ustrojami totalitarnymi. Jednocześnie trzeba jasno oddzielić wolność wypowiedzi od mowy nienawiści. Każdy ma prawo wypowiadać się krytycznie na temat systemów politycznych, religijnych, czy norm obyczajowych. Jednak nie wolno w ten sposób piętnować wyznawców danej religii, osób danego pochodzenia, czy narodowości (https://www.facebook.com/osrodek.monitorowania/).

Uwagę internautów zwróciła także akcja organizacji, która polegała na publikowaniu przepełnionych rasizmem komentarzy wraz ze zdjęciami autorów, dostępnymi na ich prywatnych profilach wspomnianego portalu społecznościowego. 
Są to zazwyczaj zdjęcia kobiet i mężczyzn, tzw. poczciwych tatusiów, czy też rodzin z dziećmi u boku. Wydawać by się mogło, że to spokojni obywatele, tolerancyjni katolicy, ale pod ich roześmianymi twarzami można zobaczyć niecenzuralne, rasistowskie i ksenofobiczne komentarze, przepełnione obelgami pod adresem imigrantów i muzułmanów. Ludzi, którzy chcą znaleźć schronienie w Europie przed niebezpieczeństwem grożącym im w ich zniszczonym przez wojnę kraju.

\section{Strach przed nieznanym, zamknięte koło}

Kryzys imigracyjny wciąż jest dużym problemem dla Unii Europejskiej i państw członkowskich, których zdania w tym temacie są mocno podzielone. W dużej mierze to właśnie przez napływ imigrantów nasiliły się rasistowskie komentarze i ogólny brak pohamowania w Internecie pod każdym artykułem związanym z uchodźcami. Uciekający przed wojną muszą zmierzyć się z niezrozumieniem i atakami nawet kilka tysięcy kilometrów od własnego kraju.

Centrum Badania Opinii Społecznej w listopadzie 2017 r. przeprowadziło badania wśród Polaków, pytając o ich stosunek do uchodźców. Ośrodek, dzięki współpracy z firmą Newspoint, przebadał nastawienie do uchodźców i imigrantów wśród internautów. Warto zaznaczyć, że nastawienie sprawdzano w roku, który uznaje się za początek kryzysu migracyjnego w Europie. Jak czytamy w raporcie opracowanym przez Katarzynę Kowalczuk, Sylwię Sobiecką i Roberta Stelmacha, badanie przeprowadzono na losowej próbie 1000 wpisów opublikowanych w mediach społecznościowych.

Spośród analizowanych publikacji 548 zostało zakwalifikowanych jako opinie internautów na temat kryzysu migracyjnego, pozostałe 452 wpisy stanowiły publikacje informacyjne i pytania niewyrażające stosunku autora do problemu uchodźców (Kowalczuk, Sobiecka, Stalmach 2018).

Ograniczona wolność słowa wynika z mowy nienawiści, którą zawdzięczamy głównie osobom wrogo nastawionym do obywateli innych krajów i napływającej fali imigrantów. Jak wynika z badań, które przeprowadził CBOS (rys. 1), tylko 6\% internautów z Polski ma pozytywne zdanie na temat pomocy imigrantom. Chcą oni pomóc każdemu, bez względu na kolor skóry czy religię. Z raportu wynika także, że nie popierają postaw osób, które myślą inaczej. Uważają ich postawę za ksenofobiczną i niezgodną z postawą chrześcijańską, tak mocno akcentowaną zwłaszcza w Polsce. Spośród osób biorących udział w dyskusji internetowej jedynie 13\% użytkowników odniosło się neutralnie do kwestii udzielenia uchodźcom schronienia w Polsce.

Są to osoby, które widzą Polskę jako członka UE - zgodnie z jej polityką nasz kraj powinien włączyć się w pomoc uchodźcom. Jednak wątpliwości budzi liczba uchodźców, którzy powinni trafić do Polski. Internauci są przeciwni narzucaniu przez UE 'kwot', uważają, że każdy kraj powinien przyjąć tylu imigrantów, ilu sam uzna za stosowne. Osiemdziesiąt jeden procent wpisów internautów negatywnie odnosi się do kwestii przyjmowania uchodźców 
do Polski. Głównymi czynnikami decydującymi o niechęci wobec uchodźców są odmienna religia i kultura (20\% wypowiedzi). Popularne stało się hasło'Stop islamizacji Europy!' (Kowalczuk, Sobiecka, Stalmach 2018).

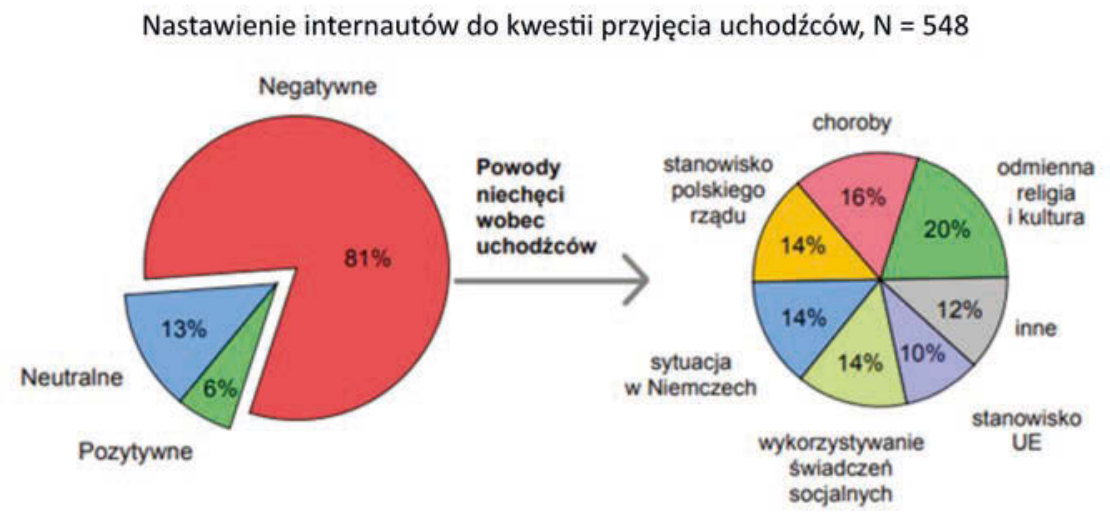

Rys. 1. Nastawienie internautów do kwestii przyjęcia uchodźców

Źródło: Centrum Badania Opinii Społecznej.

Wśród największych obaw są te o brak poszanowania polskich tradycji świeckich i religijnych, agresja w stosunku do kobiet, a także strach przed nakłanianiem do przyjęcia obcej religii - islamu.

Kolejnym czynnikiem wpływającym na niechęć do uchodźców jest obawa przed epidemiami chorób, które mogą przenosić z odległych krajów podróżujący uchodźcy (16\% wypowiedzi). Internauci, obserwując proces przyjmowania imigrantów w innych europejskich krajach, zauważają, że procedury medyczne nie są wystarczające, co prowadzi do wybuchu chorób w ośrodkach dla uchodźców. Czternaście procent wypowiedzi internautów odnosi się do wydarzeń w Niemczech: rozboje i kradzieże wśród przyjętych imigrantów, niemoc służb sanitarnych i policji, młodzieżówka CDU przeciw Angeli Merkel w sprawie uchodźców, wielotysięczne marsze przeciw imigrantom. Na skutek doniesień zza zachodniej granicy Polacy obawiają się podobnej sytuacji w kraju, więc są przeciwni imigrantom odmiennym kulturowo. Tyle samo wypowiedzi niechętnych imigrantom (14\%) odnosi się do wykorzystywania świadczeń socjalnych w państwach przyjmujących.

Internauci uważają, że większość przybyszów nie ucieka przed wojną, lecz próbuje dostać się do Europy, aby korzystać z dobrych warunków socjalnych oferowanych przez kraje UE. Polacy sprzeciwiają się traktowaniu imigrantów lepiej niż najuboższych rodaków. Również 14\% dyskutujących w Internecie sprzeciwia się polityce polskiego rządu wobec kryzysu migracyjnego, wytykając mu podporządkowanie się woli Angeli Merkel w celu uzyskania korzyści personalnych. Dziesięć procent wpisów internautów jest przeciwnych polityce UE wobec uchodźców, spekulując, że poprzez nieograniczone przyjmowanie imigrantów władze UE dążą do osłabienia tożsamości narodowej mieszkańców poszczególnych krajów. Pozostałe $12 \%$ wypowiedzi to wpisy, które nie zawierają uzasadnienia niechęci wobec imigrantów (Kowalczuk, Sobiecka, Stalmach 2018). 
To m.in. strach przed nieznanym i bezpodstawne wyobrażenia o drugim człowieku, często skrzywione przez propagandę medialną, sprawiają, że w sieci pojawia się tak wiele negatywnych komentarzy na temat imigrantów i kryzysu migracyjnego, a te z kolei wymuszają coraz bardziej ingerencyjną cenzurę, która odbierana jest jako brak wolności w sieci. Błędne rozumienie wolności słowa, jako nieograniczonej możliwości obrażania drugiej osoby, ogranicza swobodę w sieci.

\section{Zakończenie}

To, co i w jaki sposób jest publikowane świadczy o naszej kulturze osobistej. Dzięki wolności słowa możemy być kim chcemy, nie boimy się stereotypów, nie mamy obaw przed społecznym uprzedzeniem czy odrzuceniem. Niestety, ta wolność słowa w sieci, która miała nam ułatwić funkcjonowanie, porozumiewanie się i nawiązywanie kontaktów międzyludzkich, stała się swego rodzaju chorobą, która niszczy od środka. Przestaje być kulturalnym przelaniem własnych myśli w eter, a coraz częściej staje się wzajemnym obrażaniem z poczuciem bezkarności.

Wcześniej poruszane tematy blokowania stron, upubliczniania wizerunku czy komentarzy z nazwiskiem autora są przykładem bezmyślnego i nieświadomego poruszania się po świecie wirtualnym, z przeświadczeniem, że słowa napisane nikogo nie ranią, póki nie zostaną wypowiedziane face to face, a autor zostaje anonimowy. Mało optymistycznej konkluzji dokonała także agencja interaktywna Heuristic, która słusznie zauważa, że w sieci coraz częściej publikowane są wpisy czy komentarze niestosowne i wulgarne, które nie budzą już takich kontrowersji i które mało kogo już dziwią. Co więcej, podobne zachowania są coraz częściej akceptowane w serwisach, takich jak YouTube, gdzie bez problemu odnajdziemy amatorskie materiały filmowe przepełnione wulgaryzmami. $Z$ drugiej strony należy sobie zadać pytanie, czy Internet mógłby bez tego istnieć? Przecież właśnie nieograniczona, do czasu, wolność słowa jest tym, co przyciąga użytkowników.

Nigdy wcześniej na tak szeroką skalę nie mogliśmy dotrzeć do innych ludzi, prowadzić z nimi dyskusji i wypowiadać się. Internet jest medium, którego nie da się kontrolować tak jak radia czy telewizji. Jest dla nas zatem podstawowym kanałem uzyskania prawdziwej wiedzy w wielu aspektach funkcjonowania - nawet w zakresie życia politycznego. W Internecie praktycznie każdy ma szansę zaistnieć, pokazać swój potencjał, dokonania. Mamy na to mnóstwo możliwości - od komentarzy na forach, przez założenie kont w serwisach społecznościowych, witryn, blogów, dodawanie filmów, aż po profesjonalne działania promocyjne (Heuristic 2018).

Moim zdaniem wolność słowa w sieci to coś, co powinno istnieć nieprzerwanie do momentu, w którym nie naruszymy wolności innych ludzi i nie łamiemy przy tym prawa. W tych przypadkach wolność słowa powinna podlegać ograniczeniom, a wypowiedzi o charakterze rasistowskim i ksenofobicznym muszą być karane. Jednak jeśli ograniczenie wolności słowa miałoby służyć rządzącym i ludziom wpływowym do 
walki z wypowiedziami nieprzychylnymi, wówczas powinniśmy się zastanowić nad tym, w jaką stronę zmierza nasz kraj.

\section{Bibliografia}

Bychowska-Siniarska D., Głowacka D. (red.), 2013, Mowa nienawiści w internecie: jak z nią walczyć, Warszawa: Helsińska Fundacja Praw Człowieka.

Centrum Badania Opinii Społecznej, https://www.cbos.pl/SPISKOM.POL/2015/K_149_15.PDF, s. 9 [dostęp: 16.10.2018].

Chyż B., Blokowanie stron na Facebooku-ofiarami padli nie tylko „narodowcy”, http://biqdata.wyborcza.pl/biqdata/7,159116,22120323,blokowanie-stron-na-facebooku-ofiarami-padli-nie-tylko-narodowcy.html?disableRedirects=true [dostęp: 7.04.2018].

Heuristic, agencja interaktywna, Wolność słowa w internecie a granica dobrego smaku, http://www. heuristic.pl/blog/internet/Wolnosc-slowa-w-Internecie-a-granica-dobrego-smaku;174.html [dostęp: 7.04.2018].

Kowalczuk K., Sobiecka S., Stalmach R., 2015, Polacy o uchodźcach - w internecie i w "realu”, https:// www.cbos.pl/SPISKOM.POL/2015/K_149_15.PDF [dostęp: 7.04.2018].

Ośrodek Monitorowania Zachowań Rasistowskich i Ksenofobicznych, Facebook, https://www.facebook.com/osrodek.monitorowania/ [dostęp: 7.04.2018].

Ruchniewicz R., 2018, Etyka w sieci, http://krzysztofruchniewicz.eu/etyka-w-sieci/ [dostęp: 7 kwietnia 2018]. 